\title{
Checkerboard Patterns, Interspecific Competition, and Extinction: Lessons from Distribution Patterns of Tarsiers (Tarsius) and Slow Lorises (Nycticebus) in Insular Southeast Asia
}

\author{
V. Nijman • K. A. I. Nekaris
}

Received: 11 May 2009 / Accepted: 17 March 2010

(C) The Author(s) 2010. This article is published with open access at Springerlink.com

\begin{abstract}
Tarsiers (Tarsius) and slow lorises (Nycticebus) are the only extant nocturnal primates occurring in Southeast Asia. Harcourt (1999) hypothesized that in insular Southeast Asia, slow lorises and tarsiers showed a checkerboard distribution on 12 small $\left(<12,000 \mathrm{~km}^{2}\right)$ islands, i.e., only one or the other occurs, and attributed this to extreme levels of competition between these 2 largely faunivorous primates. Further, he predicted slow lorises were able to persist on smaller islands than tarsiers. We re-evaluated these findings using an expanded dataset including 49 islands where tarsiers or slow lorises occur. Tarsiers and slow lorises live on islands of similar size (median size of $c a .300-900 \mathrm{~km}^{2}$ ), and both taxa inhabit an equal proportion of small, medium, and large islands. On small islands within their area of sympatry tarsiers occur on 1 island, slow lorises on 8 , both genera on 3, and we can assume they have become extinct from 11 small islands since the Last Glacial Maximum. Sizes of islands where tarsiers or slow lorises have become extinct do not differ from islands where they are still extant. We show that slow lorises occur on more islands in insular Southeast Asia than perhaps previously assumed, but these islands are not smaller on average than islands where tarsiers occur. A checkerboard distribution between these taxa is not evident. More studies are needed at the macroecological level to assess the importance of biogeographic history in explaining their present-day distribution patterns.
\end{abstract}

Keywords Biogeography $\cdot$ Macroecology $\cdot N y c t i c e b u s \cdot$ Sundaland $\cdot$ Tarsius

\footnotetext{
V. Nijman $(\bowtie) \cdot$ K. A. I. Nekaris

Nocturnal Primate Research Group, Department of Anthropology and Geography, School of Social Science and Law, Oxford Brookes University, Oxford OX3 0BP, UK

e-mail: vnijman@brookes.ac.uk 


\section{Introduction}

Tarsiers (Tarsius) and slow lorises (Nycticebus) are the only extant nocturnal primates occurring in Southeast Asia (Fig. 1). The route via which they reached Southeast Asia is still a matter of debate. Based on early Oligocene fossils from Egypt, some authors suggest an African origin for lorises, which must have reached Asia when India collided with the Eurasian landmass (Seiffert 2007); regardless of how they arrived in Asia, the earliest fossil evidence places lorises there by 8 mya (Rasmussen and Nekaris 1998). Recent fossil evidence for tarsiers controversially suggests an ancient origin for the genus in China as early as 45 mya (Beard 1998; $c f$. Simons 2003). Persistence of a stable moist forest habitat with its associated nutrient-rich arthropods and invertebrates, combined with limited competition in the undergrowth niche, has been implicated as a factor allowing tarsiers to survive in Asia for 45 million yr (Jablonski 2003). However, modern tarsiers occur only in insular Southeast Asia including Sulawesi and the Philippines, whereas slow lorises inhabit the mainland to as far west as Northern India.

Climatic change has been implicated as a major cause for the demise of tarsiers on mainland Asia (Beard 1998). Indeed, Jablonski (2003) argued that the forests of insular Southeast Asia probably more closely resemble those inhabited by tarsiers in the Paleogene, thus explaining their persistence in this region. In examining their island distribution, Harcourt (1999) reported that in Sundaland, tarsiers (Tarsius bancanus) and slow lorises (Nycticebus coucang, N. javanicus, $N$. menagensis) showed a checkerboard distribution on small islands, i.e., only one or the other occurs. The smallest island where both species coexisted was Bangka,
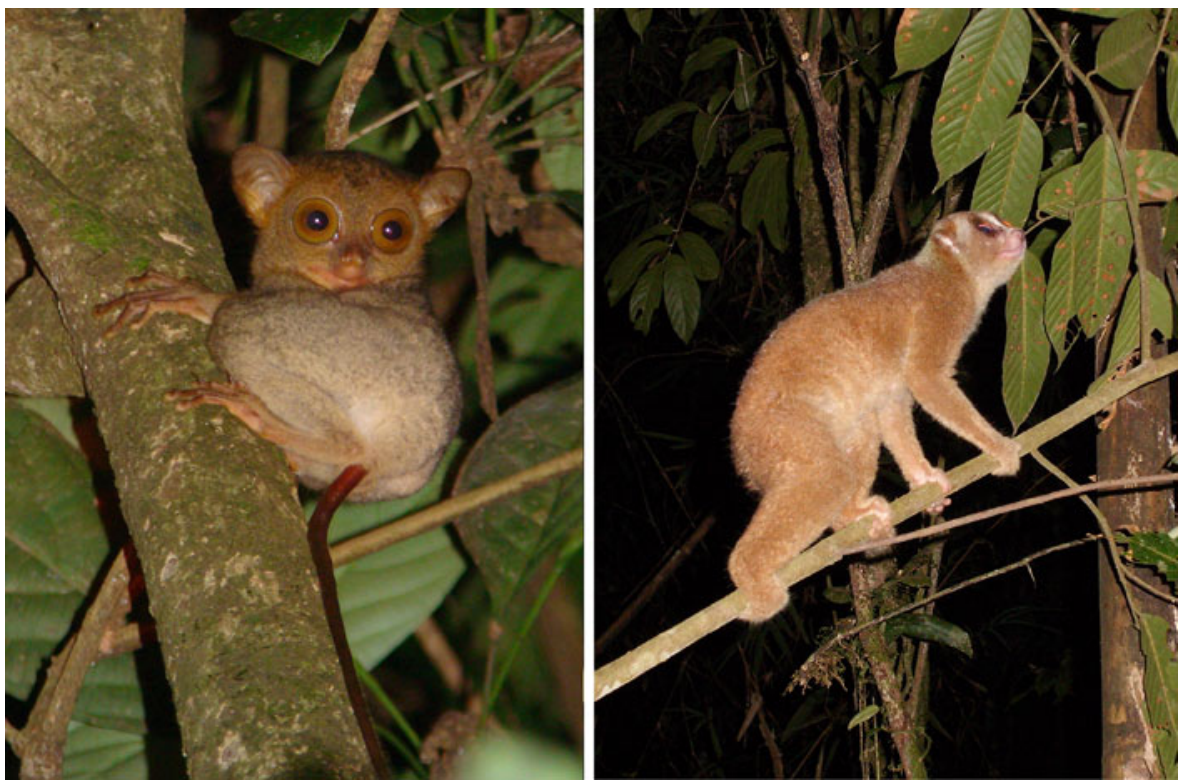

Fig. 1 Tarsius bancanus from Lower Kinabatangan Wildlife Sanctuary, Sabah, Borneo (photo: R. Munds) and Nycticebus coucang from Batu Tigi Protected Forest, Lampung, Sumatra (photo: R. Collins). Tarsiers and slow lorises live in sympatry in both areas. 
with a size of almost $12,000 \mathrm{~km}^{2}$. On islands $<100 \mathrm{~km}^{2}$ only slow lorises occur. Harcourt (1999, p. 60) noted that "The checkerboard distribution...on islands of under $11,000 \mathrm{~km}^{2}$ hints at a hitherto unforeseen high degree of competition between these two small nocturnal insectivores...given no obvious differentiation between these islands."

Diamond $(1975,1982)$, in a series of studies of Melanesian landbirds, brought checkerboard patterns into prominence by exploring why certain sets of species drawn at random from a local species pool fail to coexist at some local level. Certain species pairs or trios, e.g., flycatchers, cuckoo-doves, appeared to have mutually exclusive distributions such that any given island supported only a single species. These species were expected to have similar resource requirements, and Diamond (1975) invoked competitive exclusion as an explanation of the checkerboard distributions, with certain species co-occurrences being permissible and others forbidden. Connor and Simberloff (1979) criticized Diamond's use of competition to explain community patterns and disagreed with his tacit assumption of equilibrium. They employed a null model to test the checkerboard patterns and concluded that, given that there are so many possible sets of species, it is to be expected that a few sets are not found on any island; this does not imply that such sets are actively forbidden by any deterministic forces. They concluded that there was nothing about the absence of certain species pairs or trios that would not be expected were the birds not randomly distributed over the islands. Gotelli and McCabe (2002) revisited Diamond's data, and though they did find general support for assembly rules, with observed occurrences being less than expected than by chance, they noted that factors other than competition such as range distributions, history, habitat distributions, and stochastic drift processes may have been responsible.

Tarsiers and slow lorises exhibit a number of similar characteristics, yet in many cases adopt different strategies that may either limit or increase competition between them. For both species, vocal communication and scent marking seem to be vital for maintaining social cohesion (MacKinnon and MacKinnon 1980; Nekaris and Bearder 2007; Nietsch 2003; Shekelle 2008). Both have long gestations for smallbodied primates ( $c a .6 \mathrm{mo}$ ), yet tarsier infants are weaned within $2 \mathrm{mo}$, whereas loris infants are weaned at 6-8 mo; both primates park their infants throughout the night. Neither uses nests, preferring networks of branches, vines, and creepers as sleeping sites (Gursky 2007; Nekaris and Bearder 2007). Although tarsiers seem to be dedicated undergrowth foragers, slow lorises forage at all levels of the forest, including the canopy and undergrowth (Nekaris et al. 2008; Niemitz 1979; Merker 2006; Neri-Arboleda et al. 2002). Both slow lorises and at least some species of tarsier are relatively solitary foragers (Crompton and Andau 1986; Neri-Arboleda et al. 2002; Wiens and Zitzmann 2003); similar dietary strategies caused Niemitz to posit slow lorises (Nycticebus menagensis) as direct competitors to Tarsius bancanus (Niemitz 1984). Although exudates form a large part of slow lorises' diet, animal prey is a key resource to both slow lorises and the fully faunivorous tarsiers (Gursky 2000; Nekaris and Bearder 2007). Ravosa (1998) predicted that Nycticebus menagensis, the smallest of the region's slow lorises, based on its dental morphology, would also be the most faunivorous slow loris. Indeed, this faunivory seems to extend to the greatest competition of all, with slow lorises being a predator of the tarsiers (Niemitz 1979). 
Though the checkerboard distribution of these species being driven by competition is an intriguing hypothesis, Harcourt (1999) included only 17 islands where either or both primate occurred in his dataset. In reference to the smaller islands in the region, he included only 12 below the $11-12,000 \mathrm{~km}^{2}$ competition threshold ( 3 where only tarsiers occurred and 9 where only slow lorises occurred). However, many more islands are found within the area where both species could potentially co-occur, including a fair number that have been explored faunistically. Our aim therefore was to expand on Harcourt's dataset, to scrutinize all existing records of the occurrence of tarsiers and slow lorises in Sundaland, and test the hypothesis that these 2 nocturnal primates indeed do show a checkerboard distribution. Using these data, we also test the hypothesis that slow lorises are able to persist on smaller islands than tarsiers, and assess the critical island size for either species to coexist. More specifically, we tested the following hypotheses:

1) On islands $<12,000 \mathrm{~km}^{2}$ tarsiers and slow lorises show a checkerboard pattern of distribution, with one or the other being present but never both.

2) On islands smaller than the smallest island where both tarsiers and slow lorises occur sympatrically, they show a checkerboard pattern of distribution, with tarsiers being present on some islands and slow lorises on others.

3) Throughout insular Southeast Asia, the median size of islands on which slow lorises occur are smaller than those on which tarsiers occur.

4) Within the area of sympatry, slow lorises occur proportionally more on small islands than tarsiers.

5) Within the area of sympatry, slow lorises have become extinct from fewer small islands vs. tarsiers.

\section{Methods}

We compiled data on the occurrence of 3 species of slow loris (Nycticebus coucang, $N$. menagensis, N. javanicus) and 9 species of tarsier (Tarsius bancanus, T. dentatus, T. lariang, T. pelengensis, T. pumilus, T. sangirensis, T. syrichta, T. tarsier, $T$. tumpara) [taxonomy follows Brandon-Jones et al. 2004; Nekaris and Bearder 2007], including 49 islands from Indonesia, Myanmar, Malaysia, the Philippines, and Thailand south of the Isthmus of Kra, thus excluding the Indochinese and Indoburmese regions (Appendix 1). We obtained data from various sources as summarized in Meijaard (2003), Nijman and Meijaard (2008), and Thorn et al. (2009). In addition, we studied specimens in 7 zoological collections, obtaining data from specimen labels. In general, the distribution of slow lorises and tarsiers is well documented, but it is relevant to note where our dataset differs from Harcourt's (1999). Tarsiers do not seem to occur on Java (Niemitz 1984) and there is no evidence of slow lorises on Madura ( 2 specimens in the Zoological Museum Bogor that have been attributed to Kadungdung on Madura are in fact from Ond. [=Onderneming; Dutch, Estate] Kadondong, Pekalongan in Central Java). Slow lorises are not present on Bunguran Selatan (South Natuna Islands, which includes the island of Serasan where tarsiers occur), but they are present on Bunguran (North Natuna Islands, where there is a regency named Bunguran Selatan); Collar (2006) 
remarked on the presence of slow lorises on Jolo in the Sulu Archipelago, and we included this island in our dataset. Both tarsiers and slow lorises are present on the islands of Karimata and Belitung (Boitani et al. 2006), and tarsiers on Buton (Brandon-Jones et al. 2004).

A large number of the islands of Sundaland are merely highpoints of an immense shallow continental shelf. During the Pleistocene the shelf was exposed periodically as dry land, during glacial periods, connecting the now isolated islands into 1 large landmass. Though this would allow most species to move freely through the area, during much of the Pleistocene, dispersal between the landmasses of Sundaland, especially by terrestrial species, was limited because of barriers created by large rivers and more open vegetation types (Inger and Voris 2001; Meijaard 2003; Nijman and Meijaard 2008). Shekelle (2008) hypothesized that Tarsius bancanus expanded its range from Borneo only to include Karimata, Belitung, Bangka, and Sumatra at the end of the Last Glacial Maximum. Though intriguing, this Holocene expansion is difficult to reconcile with morphological differentiation of tarsiers on Belitung (Tarsius b. saltator), Bangka, and Sumatra (T. b. bancanus) from Borneo (T. b. borneanus) [Groves, 2001; cf. Brandon-Jones et al. 2004]. Aware of these constraints, we nevertheless assume that both tarsiers and slow lorises were distributed more widely in Sundaland during much of the Pleistocene than at present, at least occupying the area where both species occur sympatrically at present, and their absence on islands within their present-day range is probably due to Holocene extinctions.

Following Harcourt (1999) we define small islands as those smaller than the smallest island where tarsiers and slow lorises live sympatrically. In his dataset these were islands $<12,000 \mathrm{~km}^{2}$. In our expanded dataset these are islands $<120 \mathrm{~km}^{2}$. There are hundreds if not thousands of small islands and islets within the area of tarsier and slow loris sympatry where neither species occurs. In exploring Holocene extinctions of tarsiers and slow lorises we therefore restrict the analysis to islands $>50 \mathrm{~km}^{2}$ that are faunistically well explored (cf. Meijaard 2003).

When testing whether or not tarsiers and slow lorises indeed do show a checkerboard pattern, we restricted ourselves to the area where they live sympatrically. We delineated this area as follows: The easternmost boundary included the southernmost part of Sumatra and Bangka (excluding the Lingga and Riau Archipelagos), northwards to the Natuna Islands (including Bunguran), following the north coast of Borneo north as to include Balabak (but not Palawan) and the Sulu Archipelago (northeasterly as to include the island of Jolo), thence south following Borneo's east coast crossing the Java Sea into central and western Java (Fig. 2). Compared to Harcourt (1999), this area excludes 6 islands off the coast of Peninsular Malaysia and Sumatra, all with only slow lorises present, because they are at least several hundred kilometers outside the area of sympatry, i.e., Batam, Pangkor, Penang, Singapore, Tebingtinggi, and Tioman.

We used non-parametric statistics (Zar 1999) to test the hypothesis that tarsiers and slow lorises show a checkerboard pattern and the hypothesis that slow lorises are able to persist on smaller islands than tarsiers. We applied Yates' correction for continuity in $\chi^{2}$ tests where appropriate. We conducted analyses in SPSS 17; we present medians (interquartile ranges) and sample size, and accept significance when $p \leq 0.05$ in a 2 -tailed test. 


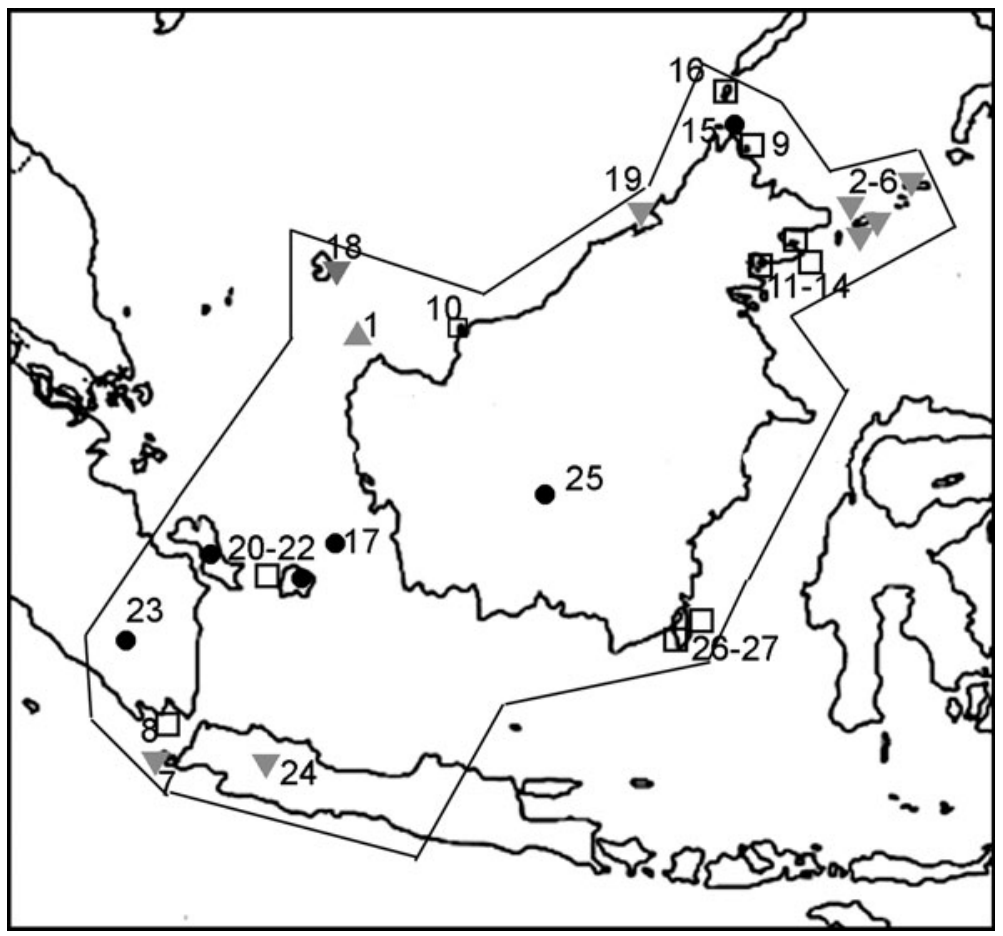

Fig. 2 Map of Sundaland showing the area of sympatry encompassed by a polygonal line. Dark circles indicate where both genera are present, empty squares show where both genera are absent, gray triangles show where only Tarsius is present, and inverted gray triangles show where only Nycticebus is present. Numbers correspond to localities listed in Table II.

\section{Results}

\section{Island Sizes}

The median island size for tarsiers $\left(873 \mathrm{~km}^{2}\right.$ [range $125-7213 \mathrm{~km}^{2}$ ], $\left.n=27\right)$ is not significantly larger than that for slow lorises $\left(329 \mathrm{~km}^{2}\left[80-1376 \mathrm{~km}^{2}\right], n=28\right)$ (Mann-Whitney $U$ test [MWU], $U=272, p=0.07$ ). The distribution of the 2 genera over islands of different sizes does not differ $\left(\chi^{2}=3.23, \mathrm{df}=3, p=0.36\right)$, nor are slow lorises found proportionally more on small islands than tarsiers $\left(\chi^{2}=2.18, \mathrm{df}=1, p=\right.$ 0.14 and $\chi^{2}=0.89, \mathrm{df}=1, p=0.34$ for small islands of $<120 \mathrm{~km}^{2}$ or $<12,000 \mathrm{~km}^{2}$, respectively; Table I).

\section{Occurrence Within Area of Sympatry}

Within insular Southeast Asia, tarsiers or lorises, or both, occur on 43 islands $<12,000 \mathrm{~km}^{2}$, on 18 only tarsiers occur, and on another 21 only slow lorises. Though this may suggest a checkerboard pattern, with only one or the other being present, the bulk of these islands are situated in the area where the 2 taxa occur allopatrically.

There are 27 islands within the sympatric area of tarsiers and slow lorises that are faunistically well explored (Table II). Seven of these are occupied by tarsiers and 15 
Table I Presence of tarsiers (Tarsius spp.) and slow lorises (Nycticebus spp.) on islands of different sizes in Southeast Asia, to showing that both taxa display a similar pattern

\begin{tabular}{lll}
\hline Island size $\left(\mathrm{km}^{2}\right)$ & Tarsier & Slow loris \\
\hline$\leq 120$ & 4 & 9 \\
$121-1200$ & 10 & 12 \\
$1201-12,000$ & 8 & 5 \\
$>12,000$ & 5 & 3 \\
\hline
\end{tabular}

by slow lorises. Apart from the large islands of Sumatra and Borneo, the 4 islands where tarsiers and slow lorises coexist are Banggi, Karimata, Belitung, and Bangka (Fig. 2). Nine islands are below the size of Banggi, the smallest island where the 2 species live sympatrically. If tarsiers were occupying these 9 small and 18 larger islands according to availability, we would expect 2.3 small islands and 4.7 larger islands to hold tarsiers; this is hardly different from the observed 1 small and 6 larger islands. The expected values for slow lorises match those of the observed values, i.e., 5 on small and 10 on larger islands. Thus, though we see more small islands

Table II Distribution of tarsius (Tarsius bancanus) and slow lorises (Nycticebus coucang, N. menagensis, $N$. javanicus) on islands within their sympatric range, ordered from small to large, with island size in $\mathrm{km}^{2}$ in parentheses

\begin{tabular}{|c|c|c|c|c|}
\hline Size & Tarsier only & Both & Lorises only & Neither \\
\hline \multirow{6}{*}{ Small } & \multirow{6}{*}{$\operatorname{Serasen}^{1}(52)$} & & Bongao $^{2}(11)$ & \\
\hline & & & $\operatorname{Siminul}^{3}(40)$ & \\
\hline & & & Labuan $^{19}(65)$ & \\
\hline & & & Sangasanga $^{4}$ (67) & Sebesi $^{8}(85)$ \\
\hline & & & & Balembang $^{11}(90)$ \\
\hline & & & Panaitan $^{7}$ (118) & Mendanau $^{21}(118)$ \\
\hline \multirow{7}{*}{ Medium } & & Banggi $^{15}(121)$ & & Timbun Mata $^{12}(131)$ \\
\hline & & Karimata $^{17}$ (179) & & Jambongan $^{9}$ (176) \\
\hline & & & & Sebuku $^{13}(221)$ \\
\hline & & & & Bangkalan $^{26}(240)$ \\
\hline & & & & Balabak $^{16}(281)$ \\
\hline & & & Tawitawi $^{6}$ (475) & Sebatik $^{14}(452)$ \\
\hline & & & & Bruit $^{10}(530)$ \\
\hline \multirow{5}{*}{ Large } & & & Jolo $^{5}(1050)$ & \\
\hline & & Belitung $^{22}$ (4788) & Bunguran $^{18}(1683)$ & Laut $^{27}$ (2057) \\
\hline & & Bangka $^{20}(11,413)$ & & \\
\hline & & Sumatra $^{23}(473,607)$ & $\mathrm{Java}^{24}(125,628)$ & \\
\hline & & Borneo $^{25}(743,244)$ & & \\
\hline
\end{tabular}

We limited island size where neither species was recorded in our dataset to those $>50 \mathrm{~km}^{2}$. Numbers in superscript correspond with those in Fig. 2 
with slow lorises than tarsiers (5 vs. 1), this is simply because slow lorises are found on more islands than tarsiers (15 vs. 7).

Considering islands $>50 \mathrm{~km}^{2}$, there are 11 islands within the sympatric range where neither of the taxa have been recorded; a number of them are large, up to $>2000 \mathrm{~km}^{2}$ (Table II). Assuming that until the end of the Last Glacial Maximum both taxa occurred on all these islands, but subsequently became extinct when the sea levels rose, we can compare sizes of islands where each taxon is extinct with those where it is extant. Median size for islands where tarsiers have become extinct $\left(230 \mathrm{~km}^{2}\right.$ [111-660 $\left.\left.\mathrm{km}^{2}\right], n=18\right)$ does not significantly differ from where they are extant $\left(4788 \mathrm{~km}^{2},\left[121-473,607 \mathrm{~km}^{2}\right], n=7\right.$; MWU=42.0, $\left.p=0.22\right)$. Median size for islands where slow lorises have become extinct (199 km $\left.\left[97-409 \mathrm{~km}^{2}\right], n=12\right)$ does not significantly differ from where they are extant $\left(475 \mathrm{~km}^{2}\left[67-11,413 \mathrm{~km}^{2}\right], n=\right.$ 15) $(\mathrm{MWU}=72.5, p=0.40)$. No differences are apparent between island sizes from where tarsiers have become extinct vs. those from where slow lorises have become extinct (MWU $=95.0, p=0.60)$.

\section{Discussion}

We found no evidence of a checkerboard pattern in the distribution of tarsiers and slow lorises on small islands in Sundaland. If we take islands of $<12,000 \mathrm{~km}^{2}$ as the threshold for small islands then these 2 nocturnal primates do not appear to have mutually exclusive distributions such that any given island supports only 1 species as on 3 islands both taxa coexist. On islands smaller than the smallest island where both tarsiers and slow lorises occur sympatrically, one is occupied only by tarsiers and 5 only by slow lorises. With slow lorises occupying about twice as many islands than tarsiers, this distribution does not deviate from what is expected. Redefining the area of sympatry to include all islands of Sundaland south of the Isthmus of Kra (Appendix 1), and ignoring the fact that this then includes islands $>1000 \mathrm{~km}$ northwest of the current distribution range of tarsiers, only reinforces the observation that slow lorises occur on more small and medium-sized islands within this newly defined area of sympatry, but does not provide any support for a checkerboard pattern of distribution between tarsiers and slow lorises.

One reviewer pointed out that the area of sympatry contains 6 small islands with only 1 species present and none with both [which corresponds to our definition of small islands], and of the larger islands there were 4 with only 1 species present and 6 with both (Table II). The ratio 6/0, 4/6 is significantly different (Fisher exact probability test, $P=0.034$ ). This shows that on larger islands we are less likely to find only 1 of the 2 species vs. smaller islands, but does not tell us anything about the mutually exclusive distributions on the smaller islands.

As noted by Harcourt (1999, 2002), slow lorises occur on a number of islands $<100 \mathrm{~km}^{2}$ (Bongao, Koh Lak, Pangkor, Siminul, Sanga-sanga, Galang, Siantan), but so do tarsiers (Maripipi, Malenge, Serasen, Togian). The distribution of the 2 taxa in terms of island size appears to be comparable, with a similar proportion of small, medium, and large islands occupied, and there is no difference between the median island size occupied by tarsiers and slow lorises. Neither throughout their range nor 
in the area of sympatry are slow lorises found on proportionally more small islands, and this seems to be independent of how we define small islands.

Islands where either tarsiers or slow lorises have become extinct since the Last Glacial Maximum, i.e., islands on the Sunda Shelf that up until 12,000 y were all connected to the Asian mainland where either or both species are no longer present, do not differ in size from islands where tarsiers and slow lorises are still present. Likewise, there is no difference in size of islands from where tarsiers have become extinct vs. those from where slow lorises have become extinct. Though some of the islands where both species occur are located $>50 \mathrm{~km}$ from the nearest other large island, such as Belitung and Karimata, intriguingly there are no records from some of the larger off-shore islands, e.g., Sebuku or Laut. Hence, though in absolute terms slow lorises occur on a greater number of small islands than tarsiers, e.g., 9 vs. 4 islands $<120 \mathrm{~km}^{2}$, this is fully in accordance with slow lorises being found on a greater number of islands. There does not appear to be a difference in extinction patterns in terms of island size between the 2 primates. We conclude that there is little support for the assertion that slow lorises are able to persist on smaller islands than tarsiers.

Though we found no support for a checkerboard distribution pattern or differential extinction, this is not to say that sympatric tarsiers and slow lorises lack competition. If such competition exists, our results show no indication that it has driven one or the other to extinction. How they do or do not share ecological space is important for a number of key reasons.

Examination of strepsirrhine and tarsier behavioral evolution, including synecological relationships, has been advocated as important for reifying established views of their phylogeny (Martin 1979, 2002). Such studies are vital for both lorises and tarsiers because their evolutionary relationships remain unresolved (Yoder 2003). Tarsiers in particular are sometimes placed as a sister group to the anthropoids, an ancient distinct lineage, or more closely allied to the strepsirrhines (Simons 2003). Burrows and Nash (2007) note that a better understanding of lorisiform primate behavior is critical to our understanding of primate origins, special senses, and social systems, whereas Fleagle (1999) maintains that a better understanding of tarsier behavioral differences may help to resolve the current debate regarding their phylogenetic position. Cartmill (1972, p. 120) pointed out that Asian lorises "are more highly specialized than any other living strepsirrhine for the mode of life whose adoption led to the differentiation of the order Primates from the other placentals." Crompton and Andau (1987, p. 43) noted that "the biology of Tarsius is crucial to any analysis of primate phylogeny." Similarly, both lorises and tarsiers have been described as being pivotal to our understanding of primate and anthropoid origins (Martin 1990; Wright et al. 2003). These assertions may lie in the fact that the living strepsirrhines and tarsiers share structural similarities with some adapids and omomyids that also occurred in sympatry (Fleagle 1999), making studies of them at the community level informative to reconstructing evolutionary scenarios (Fleagle et al. 1999). Several landmark synecological studies of strepsirrhines (CharlesDominique 1977; Charles-Dominique et al. 1980; Sussman 1974) are still widely regarded sources for our understanding of the ecological dynamics and speciation models of African and Malagasy strepsirrhines. Studies of the biology of how the behavior and ecology of tarsiers and slow lorises changes when they are or are not in sympatry can shed further light on the broad outline of nocturnal primate evolution (Martin 1979). 
The last decade has seen a dramatic increase in the number of studies conducted on nocturnal primates, but this increase has focused mainly on Madagascar. Research on lemurs has been pivotal in addressing several questions regarding primate evolution, including reconstructing the social organization of the first euprimates (Mueller and Thalmann 2000), to examine the evolution of antipredator behavior and semantic signaling in primates (Scheumann et al. 2007), and to examine the role of sperm competition in primate evolution (Kappeler 1997). Studies of Asian nocturnal primates have lagged behind those of the nocturnal lemurs. An analysis of the number of long-term field studies completed by the publication of a 2007 primate compendium reveals only 3 studies of 2 slow loris species and 9 studies of 5 tarsier species vs. 39 for nocturnal lemurs (Gould and Sauther 2007; Gursky 2007; Nekaris and Bearder 2007). Despite the distribution of these nocturnal primates all over Borneo, when assessing the distribution of primates on the island, Meijaard and Nijman (2003) had fewer records for tarsiers and slow lorises than all but 1 of the other 11 primates. Despite the paucity of data ( $c f$. Nekaris and Jaffe 2007; Nekaris and Nijman 2007; Nekaris et al. 2010), of the 12 taxa included in this study, 5 are listed as Vulnerable, 3 as Endangered, and 1 as Critically Endangered, with a further 2 listed as Data Deficient (IUCN 2008; Shekelle et al. 2008; Shekelle and Salim 2009). Many of these globally threatened species are single-island endemics. Wright (2003, p. 299) poignantly commented on the risks of extinction when species are restricted to 1 or a small number of islands.

We here have provided a more thorough overview of the distribution patterns of the nocturnal primates of insular Southeast Asia. Field data are required to unravel to what extent the current distribution of tarsiers and lorises in Sundaland reflects biogeographic history, or to examine further any evidence for competition between these primate species.

Acknowledgments We thank S. Gursky and M. Shekelle for inviting us to contribute to this volume, and for their extensive comments on the manuscript. We thank E. Meijaard for providing data on the distribution of primates in Southeast Asia. We gratefully acknowledge A. Harcourt for his key biogeographical contributions that led to this research. We thank the following individuals for access to and help with their zoological collections: H. van Grouw (Naturalis Leiden), D. Hill and P. Jenkins (Natural History Museum London), W. Stanley (Field Museum of Natural History Chicago), A. Rol (Zoological Museum Amsterdam), Boeadi (Zoological Museum Bogor), C. Yang (Raffles Museum, National University Singapore), and M. Nowak-Kemp (Natural History Museum Oxford University). We thank R. Munds and R. Collins for use of their photographs. Funding for some aspects of this study was provided by the Systematics Research Fund of the Linnaean Society, Primate Conservation Inc., the Royal Society, and from the SYNTHESYS Project, which is financed by European Community Research Infrastructure Action under the FP6 Structuring the European Research Area Programme (NL-TAF-3491). We thank 2 reviewers for helpful comments on the manuscript.

Open Access This article is distributed under the terms of the Creative Commons Attribution Noncommercial License which permits any noncommercial use, distribution, and reproduction in any medium, provided the original author(s) and source are credited.

\section{Appendix 1}

List of islands where tarsiers (Tarsius spp.) and slow lorises (Nycticebus spp.) have been recorded; for slow lorises these have been restricted to the area south of the 
Isthmus of $\operatorname{Kra}\left(\mathrm{ca} .12^{\circ} \mathrm{N}\right)$. For each island the following are presented (country/ countries; approximate size; geographical coordinates); note that there are often several alternative spellings for individual islands.

Islands with Tarsiers

Banggi (Malaysia; $121 \mathrm{~km}^{2} ; 117^{\circ} 11^{\prime} \mathrm{E}, 7^{\circ} 16^{\prime} \mathrm{N}$ ), Bangka (Indonesia; 11,413 km²; $\left.106^{\circ} 04^{\prime} \mathrm{E}, 2^{\circ} 15^{\prime} \mathrm{S}\right)$, Basilan (Philippines; $1282 \mathrm{~km}^{2}$; $122^{\circ} 00^{\prime} \mathrm{E}, 6^{\circ} 30^{\prime} \mathrm{N}$ ), Batudaka (Indonesia; $125 \mathrm{~km}^{2} ; 121^{\circ} 51^{\prime} \mathrm{E}, 0^{\circ} 24^{\prime} \mathrm{S}$ ), Belitung (Indonesia; $4788 \mathrm{~km}^{2} ; 107^{\circ} 50^{\prime} \mathrm{E}$, $2^{\circ} 53^{\prime} \mathrm{S}$ ), Biliran (Philippines; $498 \mathrm{~km}^{2}$; $124^{\circ} 28^{\prime} \mathrm{E}, 11^{\circ} 35^{\prime} \mathrm{N}$ ), Bohol (Philippines; $3864 \mathrm{~km}^{2}$; $124^{\circ} 12^{\prime} \mathrm{E}, 9^{\circ} 48^{\prime} \mathrm{N}$ ), Borneo (Indonesia, Malaysia, Brunei; 743,244 km²; $\left.113^{\circ} 00^{\prime} \mathrm{E}, 1^{\circ} 00^{\prime} \mathrm{N}\right)$, Buton (Indonesia; $5180 \mathrm{~km}^{2} ; 122^{\circ} 58^{\prime} \mathrm{E}, 5^{\circ} 00^{\prime} \mathrm{N}$ ), Dinagat (Philippines; $670 \mathrm{~km}^{2}$; $125^{\circ} 37^{\prime} \mathrm{E}, 10^{\circ} 09^{\prime} \mathrm{N}$ ), Kabaena (Indonesia; $873 \mathrm{~km}^{2} ; 121^{\circ} 55^{\prime}$ E, $5^{\circ} 15^{\prime} \mathrm{S}$ ), Karimata (Indonesia; $179 \mathrm{~km}^{2}$; $\left.108^{\circ} 53^{\prime} \mathrm{E}, 1^{\circ} 37^{\prime} \mathrm{S}\right)$, Leyete (Philippines; $7213 \mathrm{~km}^{2} ; 125^{\circ} 00^{\prime} \mathrm{E}, 10^{\circ} 50^{\prime} \mathrm{N}$ ), Malenge (Indonesia; $12 \mathrm{~km}^{2} ; 122^{\circ} 03^{\prime} \mathrm{E}, 0^{\circ} 15^{\prime} \mathrm{S}$ ), Maripipi (Philippines; $22 \mathrm{~km}^{2}$; $124^{\circ} 21^{\prime} \mathrm{E}, 11^{\circ} 47^{\prime} \mathrm{N}$ ), Mindanau (Philippines; $99,078 \mathrm{~km}^{2} ; 125^{\circ} 00^{\prime} \mathrm{E}, 7^{\circ} 30^{\prime} \mathrm{N}$ ), Muna (Indonesia; $3500 \mathrm{~km}^{2} ; 122^{\circ} 30^{\prime} \mathrm{E}, 5^{\circ} 00^{\prime} \mathrm{S}$ ), Peleng (Indonesia; $1650 \mathrm{~km}^{2} ; 123^{\circ} 15^{\prime} \mathrm{E}, 1^{\circ} 23^{\prime} \mathrm{S}$ ), Salayar (Indonesia; $670 \mathrm{~km}^{2} ; 120^{\circ}$ $30^{\prime} \mathrm{E}, 6^{\circ} 06^{\prime} \mathrm{S}$ ), Samar (Philippines; 13,429 $\mathrm{km}^{2}$; $125^{\circ} 18^{\prime} \mathrm{E}, 11^{\circ} 54^{\prime} \mathrm{N}$ ), Sangihe (Indonesia; $450 \mathrm{~km}^{2} ; 125^{\circ} 34^{\prime} \mathrm{E}, 3^{\circ} 33^{\prime} \mathrm{N}$ ), Serasen (Indonesia; $52 \mathrm{~km}^{2} ; 109^{\circ} 03^{\prime} \mathrm{E}$, $2^{\circ} 31^{\prime} \mathrm{N}$ ), Siargao (Philippines; $347 \mathrm{~km}^{2} ; 126^{\circ} 03^{\prime} \mathrm{E}, 9^{\circ} 52^{\prime} \mathrm{N}$ ), Siau (Indonesia; $125 \mathrm{~km}^{2} ; 125^{\circ} 23^{\prime} \mathrm{E}, 2^{\circ} 43^{\prime} \mathrm{N}$ ), Sulawesi (Indonesia; $182,870 \mathrm{~km}^{2} ; 121^{\circ} 00^{\prime} \mathrm{E}, 2^{\circ} 00^{\prime}$ $\mathrm{N}$ ), Sumatra (Indonesia; 473,607 $\mathrm{km}^{2} ; 102^{\circ} 00^{\prime} \mathrm{E}, 0^{\circ} 30^{\prime} \mathrm{S}$ ), Togian (Indonesia; $\left.105 \mathrm{~km}^{2} ; 121^{\circ} 56^{\prime} \mathrm{E}, 0^{\circ} 23^{\prime} \mathrm{S}\right)$

\section{Islands with Slow Lorises}

Banggi (Malaysia; $121 \mathrm{~km}^{2} ; 117^{\circ} 11^{\prime} \mathrm{E}, 7^{\circ} 16^{\prime} \mathrm{N}$ ), Bangka (Indonesia; 11,413 km²; $106^{\circ} 04^{\prime} \mathrm{E}, 2^{\circ} 15^{\prime} \mathrm{S}$ ), Batam (Indonesia; $399 \mathrm{~km}^{2}$; $104^{\circ} 02^{\prime} \mathrm{E}, 1^{\circ} 04^{\prime} \mathrm{N}$ ), Belitung (Indonesia; $4788 \mathrm{~km}^{2} ; 107^{\circ} 50^{\prime} \mathrm{E}, 2^{\circ} 53^{\prime} \mathrm{S}$ ), Bongao (Philippines; $11 \mathrm{~km}^{2} ; 119^{\circ} 47^{\prime}$ E, $5^{\circ} 02^{\prime} \mathrm{N}$ ), Borneo (Indonesia, Malaysia, Brunei; 743,244 $\mathrm{km}^{2} ; 113^{\circ} 00^{\prime} \mathrm{E}, 1^{\circ} 00^{\prime}$ $\mathrm{N}$ ), Bunguran (Indonesia; $1485 \mathrm{~km}^{2} ; 108^{\circ} 11^{\prime} \mathrm{E}, 3^{\circ} 58^{\prime} \mathrm{N}$ ), Galang (Indonesia; $74 \mathrm{~km}^{2} ; 104^{\circ} 14^{\prime} \mathrm{E}, 0^{\circ} 45^{\prime} \mathrm{N}$ ), Java (Indonesia; $125,628 \mathrm{~km}^{2} ; 110^{\circ} 00^{\prime} \mathrm{E}, 7^{\circ} 30^{\prime} \mathrm{S}$ ), Jolo (Philippines; $1050 \mathrm{~km}^{2}$; $121^{\circ} 04^{\prime} \mathrm{E}, 6^{\circ} 01^{\prime} \mathrm{N}$ ), Kadan Kyun (Myanmar; $450 \mathrm{~km}^{2}$; $98^{\circ} 22^{\prime} \mathrm{E}, 12^{\circ} 30^{\prime} \mathrm{N}$ ), Karimata (Indonesia; $179 \mathrm{~km}^{2} ; 108^{\circ} 53^{\prime} \mathrm{E}, 1^{\circ} 37^{\prime} \mathrm{S}$ ), Koh Lok (Thailand; $1 \mathrm{~km}^{2}$; $99^{\circ} 50^{\prime} \mathrm{E}, 11^{\circ} 50^{\prime} \mathrm{N}$ ), Labuan (Malaysia; $65 \mathrm{~km}^{2} ; 115^{\circ}$ $13^{\prime} \mathrm{E}, 5^{\circ} 19^{\prime} \mathrm{N}$ ), Langkawi (Malaysia; $363 \mathrm{~km}^{2}$; $99^{\circ} 46^{\prime} \mathrm{E}, 6^{\circ} 22^{\prime} \mathrm{N}$ ), Letong (Indonesia; $172 \mathrm{~km}^{2} ; 105^{\circ} 44^{\prime} \mathrm{E}, 2^{\circ} 56^{\prime} \mathrm{N}$ ), Panaitan (Indonesia; $118 \mathrm{~km}^{2} ; 105^{\circ} 11^{\prime}$ E, 6 ${ }^{\circ} 36^{\prime} \mathrm{S}$ ), Pangkor (Malaysia $21 \mathrm{~km}^{2}$; 100 $34^{\prime} \mathrm{E}, 4^{\circ} 13^{\prime} \mathrm{N}$ ), Penang (Malaysia; $295 \mathrm{~km}^{2}$; $100^{\circ} 14^{\prime} \mathrm{E}, 5^{\circ} 23^{\prime} \mathrm{N}$ ), Phuket (Thailand; $450 \mathrm{~km}^{2} ; 98^{\circ} 33^{\prime} \mathrm{E}, 7^{\circ} 55^{\prime} \mathrm{N}$ ), Sanga-sanga (Philippines; $67 \mathrm{~km}^{2}$; 119 $46^{\prime} \mathrm{E}, 5^{\circ} 05^{\prime} \mathrm{N}$ ), Siantan (Indonesia; $96 \mathrm{~km}^{2}$; $\left.106^{\circ} 14^{\prime} \mathrm{E}, 3^{\circ} 10^{\prime} \mathrm{N}\right)$, Siminul (Philippines; $40 \mathrm{~km}^{2} ; 119^{\circ} 48^{\prime} \mathrm{E}, 4^{\circ} 54^{\prime} \mathrm{N}$ ), Singapore (Singapore; $536 \mathrm{~km}^{2} ; 103^{\circ} 50^{\prime} \mathrm{E}, 1^{\circ} 21^{\prime} \mathrm{N}$ ), Sumatra (Indonesia; $473,607 \mathrm{~km}^{2}$; $102^{\circ} 00^{\prime} \mathrm{E}, 0^{\circ} 30^{\prime} \mathrm{S}$ ), Tawi-tawi (Philippines; $475 \mathrm{~km}^{2} ; 120^{\circ} 00^{\prime} \mathrm{E}, 5^{\circ}$ $13^{\prime} \mathrm{N}$ ), Tebingtinggi (Indonesia; $1598 \mathrm{~km}^{2} ; 102^{\circ} 40^{\prime} \mathrm{E}, 0^{\circ} 53^{\prime} \mathrm{N}$ ), Tioman (Malaysia; $\left.228 \mathrm{~km}^{2} ; 104^{\circ} 11^{\prime} \mathrm{E}, 2^{\circ} 47^{\prime} \mathrm{N}\right)$ 


\section{References}

Beard, K. C. (1998). A new genus of Tarsiidae (Mammalia: Primates) from the middle Eocene of Shanxi Province, China, with notes on the historical biogeography of tarsiers. B Carnegie Museum of Natural History, 34, 260-277.

Boitani, L., Catullo, I., Marzetti, M., Masi, M., Rulli, M., \& Savini, S. (2006). The Southeast Asian Mammal Databank. A tool for conservation and monitoring of mammal diversity in Southeast Asia, Instituto di Ecologia Applicata, Rome.

Brandon-Jones, D., Eudey, A. A., Geissmann, T., Groves, C. P., Melnick, D. J., Morales, J. C., et al. (2004). Asian primate classification. International Journal of Primatology, 25(1), 97-164.

Burrows, A., \& Nash, L. T. (2007). Introduction: Lorisoid evolution, morphology, and behaviour. American Journal of Primatology, 69(1), 1-5.

Cartmill, M. (1972). Arboreal adaptations and the origin of the order Primates. In R. H. Tuttle (Ed.), The functional and evolutionary biology of primates (pp. 97-122). Chicago: Aldine-Atherton, Chicago.

Charles-Dominique, P. (1977). Ecology and behavior of nocturnal primates. New York: Columbia University Press.

Charles-Dominique, P., Cooper, H. M., Hladik, A., Hladik, C. M., Pages, E., Pariente, G. F., et al. (Eds.). (1980). Nocturnal Malagasy primates: Ecology, physiology, and behavior. New York: Academic Press.

Collar, N. J. (2006). Systematic notes on Asian birds. 59. Taxonomy as tar-baby: the type locality and nomenclature of the Mindanao Bleeding-heart Gallicolumba crinigera (Pucheran, 1853). Zoologische Mededelingen Leiden, 80-5(11), 193-202.

Connor, E. F., \& Simberloff, D. (1979). The assembly of species communities: chance or competition? Ecology 60, 1132-1140

Crompton, R. H., \& Andau, P. M. (1986). Locomotion and habitat utilization in free-ranging Tarsius bancanus: a preliminary report. Primates, 27(3), 337-355.

Crompton, R. H., \& Andau, P. M. (1987). Ranging, activity rhythms, and sociality in free-ranging Tarsius bancanus: a preliminary report. International Journal of Primatology, 8(1), 43-71.

Diamond, J. M. (1975). Assembly of species communities. In M. L. Cody \& J. M. Diamond (Eds.), Ecology and evolution of communities (pp. 342-444). Cambridge: Belknap Press.

Diamond, J. M. (1982). Effects of species pool size on species occurrence frequencies: musical chairs on islands. Proceedings of the National Academy of Sciences of the United States of America, 52, 24202424.

Fleagle, J. (1999). Primate adaptation and evolution (2nd ed.). New York: Academic Press.

Fleagle, J. G., Janson, C. H., \& Reed, K. E. (1999). Primate communities. Cambridge: Cambridge University Press.

Gotelli, N. J., \& McCabe, D. J. (2002). Species co-occurrence: a meta-analysis of J.M. Diamond's assembly rules model. Ecology, 83, 2091-2096.

Gould, L., \& Sauther, M. (2007). Lorisiformes. In C. Campbell, A. Fuentes, K. MacKinnon, M. Panger, \& S. K. Bearder (Eds.), Primates in perspective (pp. 46-72). Oxford: Oxford University Press, Oxford.

Groves, C. P. (2001). Primate taxonomy. Washington: Smithsonian Institution Press.

Gursky, S. (2000). Effect of seasonality on the behaviour of an insectivorous primate, Tarsius spectrum. International Journal of Primatology, 21, 477-495.

Gursky, S. (2007). Tarsiiformes. In C. Campbell, A. Fuentes, K. MacKinnon, M. Panger, \& S. K. Bearder (Eds.), Primates in perspective (pp. 73-85). Oxford: Oxford University Press.

Harcourt, A. H. (1999). Biogeographic relationships of primates on South-East Asian islands. Global Ecology and Biogeography, 8(1), 55-61.

Harcourt, A. H. (2002). Empirical estimates of minimum viable population sizes for primates: tens to tens of thousands? Animal Conservation, 5(3), 237-244.

Inger, R. F., \& Voris, K. V. (2001). The biogeographical relations of the frogs and snakes of Sundaland. Journal of Biogeography, 28, 863-891.

IUCN. (2008). 2008 IUCN Red List of Threatened Species. Retrieved from www.iucnredlist.org (Accessed May 9, 2009).

Jablonski, N. G. (2003). The evolution of the tarsiid niche. In P. C. Wright, E. L. Simons, \& S. Gursky (Eds.), Tarsiers: Past, present, and future (pp. 35-49). New Brunswick: Rutgers University Press.

Kappeler, P. (1997). Intersexual selection and testis size in strepsirhine primates. Behavioral Ecology, 8(1), $10-19$.

MacKinnon, J. R., \& MacKinnon, K. S. (1980). The behaviour of spectral tarsiers. International Journal of Primatology, 1, 361-379. 
Martin, R. D. (1979). Phylogenetic aspects of prosimian behavior. In G. A. Doyle \& R. D. Martin (Eds.), The study of prosimian behavior (pp. 45-77). New York: New York Academic Press.

Martin, R. D. (1990). Primate origins and evolution: A phylogenetic reconstruction. London: Chapman and Hall.

Martin, R. D. (2002). Primatology as an essential basis for biological anthropology. Evolutionary Anthropology, 1, 3-6.

Meijaard, E. (2003). Mammals of south-east Asian islands and their Late Pleistocene environments. Journal of Biogeography, 30(8), 1245-1257.

Meijaard, E., \& Nijman, V. (2003). Primate hotspots on Borneo: predictive value for general biodiversity and the effects of taxonomy. Conservation Biology, 17, 725-732.

Merker, S. (2006). Habitat-specific ranging patterns of Dian's tarsiers (Tarsius dianae) as revealed by radio-tracking. American Journal of Primatology, 68, 111-125.

Mueller, A. E., \& Thalmann, U. (2000). Origin and evolution of primate social organisation: A reconstruction. Biological Reviews, 75(3), 405-435.

Nekaris, K. A. I., \& Bearder, S. K. (2007). The strepsirrhine primates of Asia and Mainland Africa: Diversity shrouded in darkness. In C. Campbell, A. Fuentes, K. MacKinnon, M. Panger, \& S. K. Bearder (Eds.), Primates in perspective (pp. 24-45). Oxford: Oxford University Press.

Nekaris, K. A. I., \& Jaffe, S. (2007). Unexpected diversity of slow lorises (Nycticebus spp.) within the Javan pet trade: Implications for loris taxonomy. Contributions to Zoology, 76(3), 187-196.

Nekaris, K. A. I., \& Nijman, V. (2007). CITES proposal highlights rarity of Asian nocturnal primates (Lorisidae: Nycticebus). Folia Primatologica, 78(4), 211-214.

Nekaris, K. A. I., Blackham, G., \& Nijman, V. (2008). Conservation implications of low encounter rates of five nocturnal primate species (Nycticebus sp.) in Southeast Asia. Biodiversity and Conservation, 17 (4), 733-747.

Nekaris, K. A. I., Starr, C. R., Shepherd, C. R., \& Nijman, V. (2010). Revealing culturally-specific patterns in wildlife trade via an ethnoprimatological approach: A case study of slender and slow lorises (Loris and Nycticebus) in South and Southeast Asia. American Journal of Primatology, 72, 877-886.

Neri-Arboleda, I., Stott, P., \& Arboleda, N. P. (2002). Home ranges, spatial movements, and habitat associations of the Philippine tarsier (Tarsius syrichta) in Corella, Bohol. Journal of Zoology, 257, $387-402$.

Niemitz, C. (1979). Results of a field study of the Western tarsier (Tarsius bancanus borneanus Horsefield, 1821) in Sarawak. Sarawak Museum Journal, 27(48), 171-228.

Niemitz, C. (1984). The biology of tarsiers. New York: Gustav Fischer Verlag.

Nietsch, A. (2003). Outline of the vocal behaviour of Tarsius spectrum: Call features, associated behaviors, and biological functions. In P. C. Wright, E. L. Simons, \& S. Gursky (Eds.), Tarsiers: Past, present, and future (pp. 196-220). New Brunswick: Rutgers University Press.

Nijman, V., \& Meijaard, E. (2008). Zoogeography of primates in insular Southeast Asia: species-area relationships and the effects of taxonomy. Contributions to Zoology, 77(2), 117-126.

Rasmussen, D. T., \& Nekaris, K. A. I. (1998). Evolutionary history of lorisiform primates. Folia Primatologica, 69, 250-285.

Ravosa, M. J. (1998). Cranial allometry and geographic variation in slow lorises (Nycticebus). American Journal of Primatology, 45(3), 225-243.

Scheumann, M., Rabesandratana, A., \& Zimmermann, E. (2007). Predation, communication, and cognition in lemurs. In S. L. Gursky \& K. A. I. Nekaris (Eds.), Primate anti-predator strategies (pp. 98-124). New York: Springer.

Seiffert, E. R. (2007). Early evolution and biogeography of lorisiform strepsirrhines. American Journal of Primatology, 69(1), 27-35.

Shekelle, M. (2008). Distribution of tarsier acoustic forms, north and central Sulawesi: With notes on the primary taxonomy of Sulawesi's tarsiers. In M. Shekelle, I. Maryanto, C. Groves, H. Schulze, \& H. Fitch-Snyder (Eds.), Primates of the oriental night (pp. 35-50). Jakarta: Indonesian Institute of Sciences (LIPI), LIPI Press.

Shekelle, M., \& Salim, A. (2009). An acute conservation threat to two tarsier species in the Sangihe Island chain, North Sulawesi, Indonesia. Oryx, 43, 419-426.

Shekelle, M., Groves, C., Merker, S., \& Supriatna, J. (2008). Tarsius tumpara: a new tarsier species from Siau Island, North Sulawesi. Primate Conservation, 23, 55-64.

Simons, E. L. (2003). The fossil record of tarsier evolution. In P. C. Wright, E. L. Simons, \& S. Gursky (Eds.), Tarsiers: Past, present, and future (pp. 9-34). New Brunswick: Rutgers University Press.

Sussman, R. W. (1974). Ecological distinctions in sympatric species of lemur. In R. D. Martin, G. A. Doyle, \& A. C. Walker (Eds.), Prosimian biology (pp. 75-108). London: Duckworth Press. 
Thorn, J. S., Nijman, V., Smith, D., \& Nekaris, K. A. I. (2009). Modelling slow loris (Nycticebus) distributions on Borneo, Java, and Sumatra: A predictive tool for assessing threats and setting conservation priorities. Diversity and Distributions, 15(2), 289-298.

Wiens, F., \& Zitzmann, A. (2003). Social structure of the solitary slow loris Nycticebus coucang (Lorisidae). Journal of Zoology, 261(1), 35-46.

Wright, P. C. (2003). Are tarsiers silently leaping into extinction? In P. C. Wright, E. L. Simons, \& S. Gursky (Eds.), Tarsiers: Past, present, and future (pp. 296-308). New Brunswick: Rutgers University Press.

Wright, P. C., Simons, E. L., \& Gursky, S. (2003). Introduction. In P. C. Wright, E. L. Simons, \& S. Gursky (Eds.), Tarsiers: Past, present, and future (pp. 1-6). New Brunswick: Rutgers University Press.

Yoder, A. D. (2003). The phylogenetic position of genus Tarsius: Whose side are you on? In P. C. Wright, E. L. Simons, \& S. Gursky (Eds.), Tarsiers: Past, present, and future (pp. 161-175). New Brunswick: Rutgers University Press.

Zar, J. (1999). Biostatistical analysis. Upper Saddle River: Prentice Hall. 